\title{
EFFECT OF HEAT EXPOSURE ON DEHYDRATION AND KIDNEY FUNCTION AMONG SEA SALT WORKERS IN THAILAND
}

\author{
Titaporn Luangwilai ${ }^{1,2}$, Mark Gregory Robson ${ }^{3}$, Wattasit Siriwong ${ }^{1,2}$
}

${ }^{1}$ College of Public Health Sciences, Chulalongkorn University, Bangkok, Thailand

${ }^{2}$ Center for Risk Analysis and Health Surveillance, Chulalongkorn University, Bangkok, Thailand

${ }^{3}$ School of Environmental and Biological Sciences, Rutgers University, New Brunswick, New Jersey, USA

\begin{abstract}
Background. Excessive heat exposure and dehydration among agricultural workers have been reported to reduce kidney function and lead to chronic kidney disease of unknown etiology $(\mathrm{CKDu})$.

Objective. This cross-sectional study aimed to assess heat exposure, factors related to dehydration and the relationship between dehydration and biomarkers of kidney function among sea salt workers in Thailand.

Material and methods. Wet bulb globe temperature (WBGT) was used at the time workers started work outdoors on salt farms. Urine-specific gravity, urine osmolarity, and serum creatinine were collected from 50 workers after work.

Results. The results showed that more than $50 \%$ of the participants were dehydrated after work. The maximum hours spent working per day was 10 . The average water intake was $1.51 \mathrm{~L}$. Urine specific gravity was highly significant correlated with urine osmolality $\left(r_{s}=0.400, p<0.01\right)$, and urine osmolality was significantly correlated with the estimated glomerular filtration rate $(\mathrm{eGFR})\left(\mathrm{r}_{\mathrm{s}}=0.349, \mathrm{p}<0.05\right)$. In bivariate analysis adjusted for age, sex, and current alcohol consumption, we found that a $\mathrm{WBGT}_{\mathrm{TWA}} \geq 30^{\circ} \mathrm{C}(\mathrm{OR}=0.08,95 \% \mathrm{CI}=0.01-0.44, \mathrm{p}=0.003)$ and hours spent working $(\mathrm{OR}=2.22,95 \%$ $\mathrm{CI}=1.42-3.47, \mathrm{p}<0.001)$ were independently associated with dehydration. This suggests that workers should increase their time spent on breaks and increase water consumption.

Conclusions. Educational program on heat exposure and heat-related illness prevention strategies should be provided.
\end{abstract}

Keywords: heat exposure, dehydration, kidney function, agricultural work

\section{INTRODUCTION}

From 2000 to 2016, approximately 125 million people were exposed to and impacted by heat waves, which represents an increase in exposure from previous periods $[1,2]$. Recent studies have examined the effects of increased heat exposure on health and have found it to be linked with heart disease, respiratory disease, and nephropathy [3, 4]. Several studies in high-heat countries, such as Nicaragua, El Salvador, and Guatemala, found that chronic kidney diseases occurs in groups of agricultural workers who engage in primarily outdoor activities and experience extreme heat exposure, such as sugarcane workers and rice farmers, without finding a common cause, such as hypertension or diabetes. Therefore, these people are classified as having chronic kidney disease of unknown etiology (CKDu). Past studies have identified possible causes of CKDu among agricultural workers, including heat exposure and dehydration $[5,6]$. CKDu is therefore another health concern for people who work outdoors in hot areas.

Normally, the core human body temperature is maintained below $38^{\circ} \mathrm{C}$ or $38.5^{\circ} \mathrm{C}$ in unacclimatized and acclimatized workers, respectively [7]. When the body temperature increases, sweat is produced to cool the body through evaporation. However, if the loss of heat through the evaporation of sweat cannot balance the exposure to heat, heat stress can occur [8]. Heat stress often occurs in conjunction with dehydration and other heat-related symptoms, such as headache, muscle cramps, and fatigue. Previous studies have not yet clarified how dehydration causes CKD, but many researchers believe that occupational heat stress and dehydration are some of the factors affecting kidney health [9].

Thailand is a country located in the tropical zone, and its inhabitants regularly engage in agriculture. Sea salt farming has been an occupation since ancient times and is still practiced today. Salt is harvested between January and May every year during periods

Corresponding author: Wattasit Siriwong, College of Public Health Sciences, Chulalongkorn University, Bangkok, Thailand, +66 2218 8184, e-mail: wattasit.s@chula.ac.th

(C) Copyright by the National Institute of Public Health NIH - National Research Institute 
of hot weather. During the harvest, human laborers using ancient techniques are the main form of labor. It is difficult work, even though there are tools that can reduce the workload to a certain degree. Salt farm workers work 4-10 consecutive hours a day and are inevitably exposed to heat because salt farms are in open areas with no available shade, even during breaks. Previous studies of the health effects of this type of work on salt farm workers found signs and symptoms associated with heat exposure. However, studies assessing biomarkers have been lacking.

The objectives of this study were to assess heat exposure, possible factors related to dehydration and the relationship between dehydration and biomarkers of kidney function in salt farm workers.

\section{MATERIAL AND METHODS}

\section{Study site and population}

As salt farming is a seasonal production, the land will be prepared before the rainy season starts. The harvest season will start around January or February and end before the rainy season (May-June). This cross-sectional study was conducted on the first week of February 2020 when the first round of salt was ready to be harvested. Samut Sakhon Province, an area approximately $45 \mathrm{~km}$ south of Bangkok, is one of three largest areas for sea salt farming and has established a sea salt learning center to share relevant knowledge with local farmers and anyone else who is interested. In this study, the sea salt workers were from the Khok Kham subdistrict, the largest area in Samut Sakhon Province. The protocol of this study was presented to the chairman of the sea salt learning center by our research team, and the chairman provided a list of workers in this area (approximately 80 workers). We randomly selected males and females who had worked on salt farms for at least 1 harvest season, were aged between 18-60 years, and did not report having a history of hypertension, diabetes or kidney disease. After excluding those workers who did not meet the eligible criteria, 50 workers met the eligibility criteria, were willing to participate in this study, and signed informed consent forms. The workers on the sea salt farm were separated into five categories: farm owners, deliverers, extractors, pilers, and scoopers. The deliverers are men, who scoop the salt from the pile into the cart and push the cart to the storeroom. The extractors are both male and female workers, and they extract the salt from the ground using a wooden tool. The pilers form the salt into triangular piles. Farm owners usually drive a compactor, check the sea water level in each pond, and test the salinity. Lastly, scoopers help the deliverers scoop the salt into carts. They work as a team and do not switch roles.
With regard to the workload [10], deliverers and extractors perform "heavy work (>350 kcal/hr)", pilers and scoopers perform "moderate work (200$350 \mathrm{kcal} / \mathrm{hr})$ ", and farm owners perform "light work $(<200 \mathrm{kcal} / \mathrm{hr})$ )". Agrochemicals are not used in any step in the process of salt farming. Sea salt workers normally wear long pants and short-sleeved or longsleeved shirts. Most wear sandals or socks; a few wear boots while working. Some workers use hats or fabric to cover their faces or sunglasses. Workers bring their own water and beverages from home. They can refill their bottles with water provided by the owner of the salt farm. All participants received a marked bottle to measure their water intake while working. This study was approved by the Ethics Review Committee for Research Involving Human Research Subjects, Health Science Group, Chulalongkorn University, Thailand (COA No. 035/2020)

\section{Data collection}

Data were collected on sea salt farms during the harvest season. Heat exposure data were collected on two days in the same week in the study area. Subjects worked on sea salt farms in the area for at least 2 weeks. The participants were assumed to be acclimatized to heat. A standardized wet bulb globe temperature (WBGT) monitor, model ISO 7243 (3M QUEST temp $32^{\circ}$ ), was used to measure ambient conditions 1.25 $\mathrm{m}$ above the ground. WBGT data collection started when the workers began to work outdoors on the salt farms. The monitor was set up as close to the workers as possible and calibrated before use. Digital data were recorded every hour, and six parameters were measured: natural wet bulb temperature (Twb), dry bulb temperature (Tdb), globe bulb temperature $(\mathrm{Tg})$, WBGT, relative humidity $(\% \mathrm{RH})$, and heat index $(\mathrm{HI})$. The average WBGT was calculated, using the hour individuals worked, as the time-weighted average WBGT ( $\mathrm{WBGT}_{\mathrm{TWA}}$ ) for all individuals to determine their heat exposure. Individual skin temperatures were measured with a forehead infrared thermometer while the workers were working on the sea salt farm.

After-shift data were collected at the sea salt learning center, which is located in the middle of the sea salt area; the learning center was spacious and clean, and a toilet was available. Medical examinations and blood collection were performed by medical technicians from hospitals in the area interested in health-promoting activities. First, urine samples were collected in standard polypropylene specimen containers, and each participant provided $20-50 \mathrm{ml}$ of mid-steam urine. For the urinalysis, the urine specific gravity, urine osmolarity, urine creatinine, $\mathrm{pH}$ and color were recorded. Next, medical examinations, including measurements of blood pressure, pulse rate, weight, and height, were performed. Then, 2-3 
$\mathrm{ml}$ of blood was drawn and used to test the levels of kidney biomarkers, namely, serum creatinine, blood urea nitrogen [11] and uric acid. Finally, validated questionnaires were used to ask participants about their characteristics and exposure factors, including age, alcohol consumption and smoking, medical and herbal supplement intake, water and other beverage intake, frequency of urination, work experience on salt farms, hours spent working, and heat-related symptoms. Blood and urine samples were packed on ice and immediately sent to a certified laboratory. The methods of analysis were the following; reflectance photometry was used for urine specific gravity, freezing point depression method for urine osmolality and Jaffe's kinetic method was used for serum creatinine.

\section{Statistical analysis}

Data analyses were performed using SPSS version 22 for Windows. Descriptive statistics, including frequencies, percentages and medians (IQRs), were used to describe the characteristics and heat exposure factors. Nonnormally distributed variables were tested with the Kolmogorov-Smirnov test. For primary outcome, associations between dehydration and exposure factors, including age, sex, use of herbal supplements, smoking and alcohol consumption, workload, WBGT, water intake, other beverage intake, hours spent working and work experience, were tested with binary logistic regression. Significant predictors of CKD identified in previous studies, including age, sex and current alcohol consumption, were used as covariates [12]. For secondary outcomes, associations between dehydration, based on the urinalysis, and kidney biomarkers, as measured in the blood samples, were tested with Spearman's correlation analysis.

\section{RESULTS}

The sea salt workers were $58 \%$ male, with an average age of 47.16 years. More than half of the participants did not drink alcohol $(60 \%)$ and were nonsmokers $(68 \%)$. The average water intake on the study day was 1.53 liters (approximately 70\% was accounted for by other beverages). Approximately half of the participants had worked at sea salt farms for more than 15 years. Fifty-six percent of participants worked more than 4 hours, $70 \%$ took fewer than two rest breaks, and 50\% wore long-sleeved shirts with long pants. In total, $48 \%$ engaged in heavy work, $36 \%$ in moderate work, and $16 \%$ in light work. Most workers did not feel hotter than normal on the study day $(90 \%)$; however, $44 \%$ of the workers had heatrelated symptoms (Table 1).

As presented in Figure 1, heat exposure measurements at the sea salt farms started at 6:00 AM
Table 1. Sea salt worker characteristics and exposure factors in Thailand $(\mathrm{n}=50)$

\begin{tabular}{|l|c|}
\hline \multicolumn{1}{|c|}{$\begin{array}{c}\text { Characteristics and exposure } \\
\text { factors }\end{array}$} & $\begin{array}{c}\mathrm{n}(\%), \text { mean, } \\
\text { median (IQR) }\end{array}$ \\
\hline Sex & $29(58.0)$ \\
\hline Male & $21(42.0)$ \\
\hline Female & $47.16,51.0(41.75$ \\
\hline Age (years) & $6(12.0)$ \\
\hline$<29$ & $5(10.0)$ \\
\hline $30-39$ & $12(24.0)$ \\
\hline $40-49$ & $27(54.0)$ \\
\hline$>50$ & \\
\hline Alcohol consumption status & $30(60.0)$ \\
\hline No & $20(40.0)$ \\
\hline Yes & \\
\hline Smoking status & $34(68.0)$ \\
\hline No & $16(32.0)$ \\
\hline Yes & $1.53,1.50(1.0,2.0)$ \\
\hline Water intake, L & $21(42.0)$ \\
\hline$\leq 1$ & $29(58.0)$ \\
\hline$>1$ & \\
\hline Other beverage intake & $22(44.0)$ \\
\hline No & $15(30.0)$ \\
\hline Yes & $35(70.0)$ \\
\hline Working experience & $16.24,12.50(5.0$, \\
\hline$<15$ yrs & $25.0)$ \\
\hline$\geq 15$ yrs & $26(52.0)$ \\
\hline Hours spent working & $48(48.0)$ \\
\hline$\leq 4$ hours & $22(44.0)$ \\
\hline$>4$ hours & $25(56.0)$ \\
\hline Number of breaks & $35(70.0)$ \\
\hline$\leq 2$ & $15(30.0)$ \\
\hline$>2$ & \\
\hline Clothing & \\
\hline $\begin{array}{l}\text { Short-sleeved/long-sleeved shirt } \\
+ \text { shorts/long pants }\end{array}$ \\
\hline Long-sleeved shirt+ long pants & \\
\hline Workload & \\
\hline Light work & \\
\hline Moderate work & \\
\hline Heavy work & \\
\hline Felt hotter than normal & \\
\hline No & \\
\hline Yes & \\
\hline
\end{tabular}




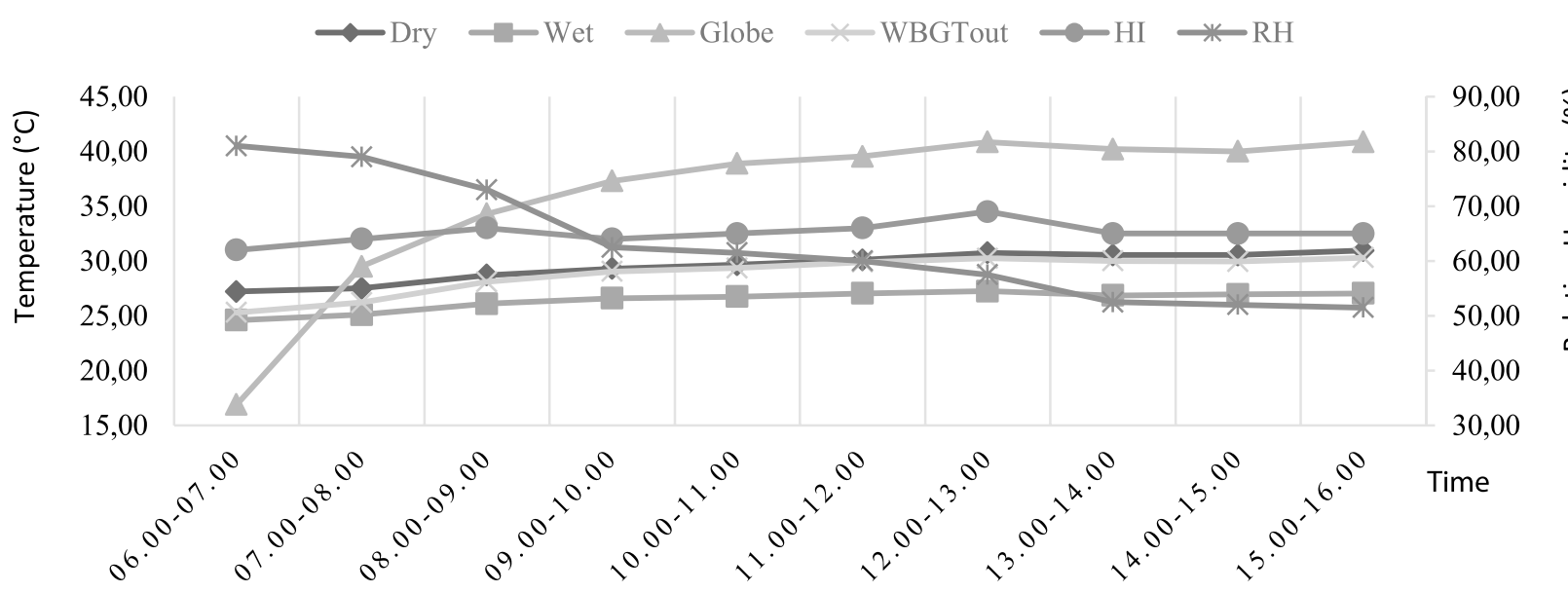

Figure 1. Heat exposure monitored by wet bulb globe temperature measurements on a sea salt farm

(Dry=Dry Bulb Temperature; Wet=Wet Bulb Temperature; Globe=Globe Bulb Temperature; WBGTout=Wet Bulb Globe Temperature Outdoor; $\mathrm{HI}=$ Heat Index; $\mathrm{RH}=$ Relative Humidity)

and continued until 4:00 PM. The WBGT over the 2 days varied from $25.30^{\circ} \mathrm{C}$ to $30.30^{\circ} \mathrm{C}$, and the average was $28.84^{\circ} \mathrm{C}$. The dry bulb temperature varied from $27.20^{\circ} \mathrm{C}$ to $30.95^{\circ} \mathrm{C}$, and the average was $29.53^{\circ} \mathrm{C}$. The wet bulb temperature varied from $24.60^{\circ} \mathrm{C}$ to $27.25^{\circ} \mathrm{C}$, and the average was $26.43^{\circ} \mathrm{C}$. The globe bulb temperature varied from $16.90^{\circ} \mathrm{C}$ to $40.85^{\circ} \mathrm{C}$, and the average was $35.84^{\circ} \mathrm{C}$. The $\mathrm{RH}$ ranged from 51.50 to $81.00 \%$, with an average of $63.05 \%$. The mean HI was $32.55^{\circ} \mathrm{C}$. The $\mathrm{WBGT}_{\mathrm{TWA}}$ calculated to determine individual heat exposure on each working day was $29.83^{\circ} \mathrm{C}$.

Most of the participants had urine that was yellow (72\%) and not cloudy (82\%). The median urine $\mathrm{pH}$ was 5.26 , the urine specific gravity was 1.025 , the urine creatinine level was $189.05 \mathrm{~g} / \mathrm{L}$, and the urine osmolality was $863 \mathrm{mOsm} / \mathrm{L}$. The median levels of the serum biomarkers were as follows: serum creatinine, $0.9 \mathrm{mg} / \mathrm{dL}$; blood urea nitrogen, $13.0 \mathrm{mg} / \mathrm{dL}$; and uric acid, $6.85 \mathrm{mg} / \mathrm{dL}$. In total, $58 \%$ of the workers were not dehydrated, while $42 \%$ were dehydrated. The eGFR, calculated with the CKD-EPI equation, showed that $52 \%$ of the workers were defined as having stage 1 CKD, and three out of $50(6 \%)$ workers had low eGFR $\left(<60 \mathrm{ml} / \mathrm{min} / 1.73 \mathrm{~m}^{2}\right)$ (Table 2).

Based on results from binary logistic regression, $\mathrm{WBGT}_{\mathrm{TWA}} \geq 30^{\circ} \mathrm{C}(p=0.003)$ was significantly associated with dehydration. Those workers that were exposed to high heat, based on a $\mathrm{WBGT}_{\mathrm{TWA}} \geq 30^{\circ} \mathrm{C}$, were 0.11 times more likely to be dehydrated than with a $\mathrm{WBGT}_{\mathrm{TWA}}<30^{\circ} \mathrm{C}$. Moreover, the number of hours spent working was significantly associated with dehydration $(p<0.001)$, and each unit increase in the number of hours spent working increased the odds of dehydration 2 times (OR $=2.0,95 \%$ CI 1.37-2.91). Then, after adjusting for age, sex, and current alcohol consumption, we found that a $\mathrm{WBGT}_{\mathrm{TWA}} \geq 30^{\circ} \mathrm{C}(\mathrm{OR}$ $=0.08,95 \% \mathrm{CI}=0.01-0.44, \mathrm{p}=0.003)$ and the number
Table 2. Biomarkers in Sea Salt Workers in Thailand $(n=50)$

\begin{tabular}{|c|c|}
\hline Biomarkers & $\mathrm{n} \%$, median (IQR) \\
\hline \multicolumn{2}{|l|}{ Urine biomarkers } \\
\hline \multicolumn{2}{|l|}{ Color } \\
\hline Pale yellow & $5(10.0)$ \\
\hline Yellow & $36(72.0)$ \\
\hline Deep yellow & $4(8.0)$ \\
\hline Orange & $2(4.0)$ \\
\hline Brown & $3(6.0)$ \\
\hline \multicolumn{2}{|l|}{ Appearance } \\
\hline Clear & $41(82.0)$ \\
\hline Turbid & $9(18.0)$ \\
\hline $\mathrm{pH}$ & $5.26 \pm 0.52$ \\
\hline Urine specific gravity & $1.025(1.02,1.03)$ \\
\hline Urine creatinine $(\mathrm{g} / \mathrm{L})$ & $\begin{array}{c}189.05 \\
(140.0,247.825)\end{array}$ \\
\hline Urine osmolality (mOsm/L) & $\begin{array}{c}863.0 \\
(675.25,953.0) \\
\end{array}$ \\
\hline \multicolumn{2}{|l|}{ Serum biomarkers } \\
\hline Serum creatinine (mg/dL) & $0.9(0.8,1.1)$ \\
\hline Blood urea nitrogen (mg/dL) & $13.0(11.0,16.0)$ \\
\hline Uric acid (mg/dL) & $6.85(5.70,7.85)$ \\
\hline \multicolumn{2}{|l|}{$\begin{array}{l}\text { Hydration status based on urine } \\
\text { specific gravity }\end{array}$} \\
\hline Euhydration $(\leq 1.025)$ & $29(58.0)$ \\
\hline Dehydration $(>1.025)$ & $21(42.0)$ \\
\hline \multicolumn{2}{|l|}{ Kidney function } \\
\hline $\begin{array}{l}\text { Estimated glomerular filtration } \\
\text { rate, eGFR-EPI, } \mathrm{ml} / \mathrm{min} / 1.73 \mathrm{~m}^{2}\end{array}$ & $90.60(72.08,99.43)$ \\
\hline \multicolumn{2}{|l|}{$\begin{array}{l}\text { Reduced kidney function stage, } \mathrm{n} \\
(\%) \text { - eGFR-EPI }\end{array}$} \\
\hline Stage 1, eGFR > 90 & $26(52.0)$ \\
\hline Stage 2, eGFR 60-90 & $21(42.0)$ \\
\hline Stage 3a, eGFR 45-59 & $3(6.0)$ \\
\hline
\end{tabular}


of hours spent working $(\mathrm{OR}=2.22,95 \% \mathrm{CI}=1.42$ $3.47, \mathrm{p}<0.001)$ were independently associated with dehydration, as shown in Table 3.

The correlation between hydration status and kidney function showed that the urine specific gravity was correlated with urine osmolality $\left(\mathrm{r}_{\mathrm{s}}=0.400, \mathrm{p}<\right.$ 0.01 ), and urine osmolality was correlated with the eGFR $\left(r_{s}=0.349, p<0.05\right)$, as shown in Table 4 .

\section{DISCUSSION}

The sea salt workers in this study were local Thai people living in Samut Sakhon Province. More workers were male, and their ages ranged from 18 to 60 years old. They had an average of 12.5 years of experience working on salt farms. The number of hours spent working each day ranged from 2 to 10 , depending on how many salt ponds were ready to be harvested. Each salt pond takes approximately 2-3 hours to harvest, and workers harvested between 1 and 3 pounds per day. Many jobs on agricultural farms involve heavy workloads, including sugarcane cutting, corn farming and rice farming. In this study, many workers had heavy workloads. Sea salt farm activities involve intense manual labor, repetitive movements, whole-body movements, few breaks, and long periods spent working in the heat. The delivery task was the most labor intensive job on these salt farms, and only men performed this task. Other jobs, including extracting the salt, piling the salt, scooping the salt and managerial tasks, were performed by both male and female workers. A previous study on sea salt workers in Thailand involved a population that was $75 \%$ male, with an average age of 36.6 years [13].

Heat exposure was measured by the WBGT, a gold standard for studies investigating occupational heat stress. The recorded WBGT varied from $25.30^{\circ} \mathrm{C}$ to $30.30^{\circ} \mathrm{C}$, with an average of $28.84^{\circ} \mathrm{C}$. Overall, the average level of heat exposure was not greater than that stipulated in the regulations for those working in hot conditions (heavy work should not be performed when the temperature is over $30^{\circ} \mathrm{C}$, moderate work

Table 3. Binary logistic regression predicting dehydration based on urine-specific gravity in sea salt farm workers in Thailand $(\mathrm{n}=50)$

\begin{tabular}{|c|c|c|c|c|c|c|}
\hline \multirow{2}{*}{ Variables } & \multicolumn{2}{|c|}{ Univariate } & \multirow{2}{*}{$\mathrm{p}$-value } & \multicolumn{2}{|c|}{ Adjusted** } & \multirow{2}{*}{$\mathrm{p}$-value } \\
\hline & OR & $95 \% \mathrm{CI}$ & & OR & $95 \% \mathrm{CI}$ & \\
\hline Age $\geq 40$ years & 2.28 & $0.52-9.92$ & 0.270 & 2.28 & $0.51-10.15$ & 0.276 \\
\hline Male sex & 0.94 & $0.30-2.93$ & 0.917 & 0.90 & $0.28-4.20$ & 0.903 \\
\hline Use of herbal supplement & 0.65 & $0.05-7.97$ & 0.755 & 0.54 & $0.04-7.21$ & 0.642 \\
\hline Current smoking & 1.61 & $0.48-5.36$ & 0.433 & 1.81 & $0.39-8.32$ & 0.441 \\
\hline Current alcohol consumption & 0.87 & $0.27-2.75$ & 0.872 & 0.92 & $0.23-3.63$ & 0.910 \\
\hline Medium-heavy workload & 0.36 & $0.07-1.75$ & 0.211 & 0.34 & $0.06-1.68$ & 0.188 \\
\hline $\mathrm{WBGT}_{\mathrm{TWA}} \geq 30^{\circ} \mathrm{C}$ & 0.11 & $0.02-0.49$ & $0.003^{*}$ & 0.08 & $0.01-0.44$ & $0.003^{*}$ \\
\hline Water intake $\leq 1 \mathrm{~L}$ & 0.53 & $0.16-1.71$ & 0.293 & 0.52 & $0.16-1.74$ & 0.295 \\
\hline No intake of other beverages & 0.59 & $0.16-2.09$ & 0.418 & 0.56 & $0.14-2.10$ & 0.392 \\
\hline Hours spent working ${ }^{\mathrm{b}}$ & 2.00 & $1.37-2.91$ & $<0.001^{*}$ & 2.22 & $1.42-3.47$ & $<0.001^{*}$ \\
\hline Work experience & 1.05 & $1.00-1.11$ & 0.023 & 1.05 & $1.00-1.11$ & 0.044 \\
\hline
\end{tabular}

* Association significant at $\mathrm{p}<0.05, * *$ Adjusted for age, sex, current alcohol consumption

${ }^{\mathrm{a}}$ Urine specific gravity $(0 \leq 1.025$ and $1>1.025),{ }^{\mathrm{b}}$ Continuous data

Table 4. Spearman's correlation analyses of the associations between hydration and kidney function $(\mathrm{n}=50)$ in sea salt workers in Thailand

\begin{tabular}{|c|c|c|c|}
\hline \multirow{2}{*}{ Predictor } & \multicolumn{2}{|c|}{ Spearman's correlation coefficient $\left(\mathrm{r}_{\mathrm{s}}\right)(\mathrm{p}$-value $)$} \\
\cline { 2 - 4 } & \multicolumn{2}{|c|}{ Hydration status } & Kidney function \\
\cline { 2 - 4 } & urine specific gravity & urine osmolality & eGFR \\
\hline Hydration status & 1.00 & & \\
\hline Urine specific gravity & $\mathbf{0 . 4 0 0 * *}(\mathbf{0 . 0 0 4})$ & & 1.00 \\
\hline Urine osmolality & & & \\
\hline Kidney function & $0.089(0.540)$ & $\mathbf{0 . 3 4 9 *}(\mathbf{0 . 0 1 3})$ & 1.00 \\
\hline eGFR & & & \\
\hline
\end{tabular}

* Correlation is significant at the 0.05 level (2-tailed)

** Correlation is significant at the 0.01 level (2-tailed) 
should not be performed when the temperature is over $32^{\circ} \mathrm{C}$, light work should not be performed when the temperature is over $34^{\circ} \mathrm{C}$ ) [14]. Samut Sakhon Province is approximately 1-2 meters above sea level (masl). In general, regions at relatively low altitudes and coastal areas ( $<500$ meters above sea level; masl) have higher temperatures than regions at relatively high altitudes $(\geq 500$ masl), and the difference is approximately $4^{\circ} \mathrm{C}$ [15]. The mean WBGT increased over the course of the morning and was the highest at noon. Sea salt workers continue to work at noon because their tasks have to be finished, and only $30 \%$ of the workers took more than 2 breaks. The Occupational Safety and Health Administration [16] has recommended maintaining an appropriate WBGT in the work environment to avoid excessive increases in body temperature. Workers should rest $75 \%$ of the time when WBGT exceeds $30^{\circ} \mathrm{C}$ (OSHA1999). Field workers are more frequently exposed to heat than workers in other areas [12]. A study of the health impact of climate change in Thailand included 5 types of worksites: sites in the pottery industry, power plants, sites in the knife industry, construction sites and agricultural sites. The outdoor WBGT ranged from $25.2^{\circ} \mathrm{C}-34.6^{\circ} \mathrm{C}$, and the highest was $34.6^{\circ} \mathrm{C}$ at the agricultural sites [17]. Moreover, this study reported that most workers did not feel hotter than normal on the study day, although $44 \%$ of the workers had heatrelated symptoms, which was similar to the findings of a previous study on a salt farm that reported an average WBGT of $33.83^{\circ} \mathrm{C}$ and heat-related symptoms in $50.88 \%$ of the workers, despite the fact that they did not feel hotter than normal $(53.22 \%)$. This study found a moderate positive correlation between heatrelated symptoms and the WBGT [13]. The WBGT in our study did not exceed the recommendation in the regulations, but nearly half of the workers had heatrelated symptoms.

Hydration was assessed with urine biomarkers, which is a convenient method for a field study. The urine biomarkers included urine specific gravity and urine osmolarity. Urine specific gravity is the most popular biomarker of hydration, while urine osmolarity is considered a good marker, with a sensitivity of $91 \%$ and an adequate specificity for dehydration [18, 19]. We collected urine samples from each worker immediately after work. The criteria for dehydration were a urine specific gravity $>1.025 \mathrm{~g} / \mathrm{ml}$ [20] and a urine osmolarity $>700 \mathrm{mOsm} / \mathrm{L}$ [21]. The median urine specific gravity and median urine osmolarity were at the upper limits of euhydration. Twentyone sea salt workers had urine specific gravity that indicated that they were dehydrated. This is similar to the findings in a study involving miners, in which $42 \%$ of the population was dehydrated after work [22]. Several studies on dehydration in agricultural workers have noted that working in hot temperatures, the loss of water and electrolytes, an imbalance in the core body temperature, high humidity and a heavy workload can lead to dehydration [23].

The intake of water and the intake of other beverages were not associated with dehydration. Workers in this study had an insufficient intake of liquids. This may be due to their jobs, which required them to work in long stretches without stopping (2-3 hours). Participants consumed beverages other than water, such as energy drinks, electrolyte drinks, sugary drinks and coffee. The average amount of water consumed on a work day was $1.5 \mathrm{~L}$, which is less than the recommended amount. To prevent heat-related illness, the American Conference of Governmental Industrial Hygienists recommended threshold limit value [7] is approximately $235 \mathrm{ml}$ of water every 20 minutes when working in a hot environment. Thus, to prevent dehydration, sea salt workers should increase their water intake and number of breaks while working.

Kidney function was monitored by the eGFR. The CKD-EPI formula was used to calculate the eGFR in this study [24]. The average post-shift serum creatinine level in these sea salt workers was higher than that in a previous study among sugarcane workers in Nicaragua [25] but lower than that in another study in sugarcane workers in El Salvador [26]. Moreover, the average post-shift eGFR in sea salt workers was lower than that in previous studies in sugarcane workers in several countries, such as Nicaragua, El Salvador and Guatemala [25-27]. Sugarcane workers work in hot conditions, with a WBGT ranging from $30.9^{\circ} \mathrm{C}-35.5^{\circ} \mathrm{C}$, which is similar to the work environment experienced by sea salt workers; however the tasks and other aspects of the work environment are different. Salt farms are open, and there are no shady spots or tents in which to rest. The wage is earned by the entire team, unlike sugarcane workers, who are paid individually. This encourages sea salt workers to continue their work until they are finished, without taking a break; they try to hurry to finish and start another round of harvesting.

Many studies have concluded that the decreased kidney function indicated by the eGFR value after work was due to several occupational factors that led to heat stress and dehydration. Urine specific gravity and urine osmolarity increase with dehydration[20]. We found that dehydration, as indicated by urine specific gravity, was significantly related to urine osmolarity $(\mathrm{r}=0.400)$. Two cross-sectional studies on heat exposure and dehydration were conducted in Sri Lanka [20] and Japan [21]. The study in Sri Lanka showed that approximately $40 \%$ of the paddy farmers were dehydrated after work and that there was a significant correlation between urine specific gravity and urine osmolarity $(\mathrm{r}=0.917)$ [20], while the study 
of 23 construction workers in Japan found that 21\% of the workers were dehydrated and that there was a strong correlation between urine specific gravity and urine osmolarity $(\mathrm{r}=0.87)$ [21]. Moreover, our study showed that urine osmolarity was significantly related to the eGFR $(r=0.349)$. Workers at lower altitudes are more likely to be exposed to heat than those at higher altitudes; heat exposure can cause dehydration and is related to the development of CKD [26]. The loss of water from the body stimulates the release of the hormone vasopressin, causing the urine to become more concentrated and also causes renal vasoconstriction, which is associated with the GFR. If the water loss is severe or prolonged, it can impair the GFR or cause ischemia, leading to acute kidney injury (AKI) [1]. There is evidence that if AKI is sustained and prolonged, it can progress to CKD [8].

This study has several limitations. First, the sea salt workers were randomly selected from only one area of the salt farm, and the sample size was limited. Second, we only obtained one set of urine and blood samples after work. Third, we measured only the volume of water intake. We did not measure the volume of other beverages consumed, which could be linked to dehydration. However, we found that many of the workers were dehydrated and that there were relationships between heat exposure and dehydration and between dehydration and kidney biomarkers.

\section{CONCLUSIONS}

This study provides new evidence that sea salt workers are at a relatively higher risk of CKDu in countries affected by climate change. The findings showed that these workers have a heavy physical workload in a hot environment, and sea salt workers were found to be dehydrated after work, which could lead to a decrease in kidney function. We suggest that workers should increase their number of breaks and their intake of liquids. Education on hazardous heat exposure and heat-related illness prevention strategies should be provided.

\section{Acknowledgements}

The authors acknowledge supported of Grant for International Research Integration: Chula Research Scholar, Ratchadaphiseksomphot Endowment Fund (GCURS 59-06-79-01) and Office of International Affairs Scholarship for Short-term Research, Chulalongkorn University, Thailand, NIH-NIEHS P30 ES005022, and the New Jersey Agricultural Experiment Station, Rutgers University, USA.

\section{Conflict of interest}

The authors declare no conflict of interest.

\section{REFERENCES}

1. Lozano, R.N., Mohsen Foreman, Kyle Lim, Stephen Shibuya, Kenji Aboyans, Victor, et al.: Global and regional mortality from 235 causes of death for 20 age groups in 1990 and 2010: a systematic analysis for the Global Burden of Disease Study 2010. The Lancet 2012;380(9859):2095-2128 doi: 10.1016/S01406736(12)61728-0.

2. Watts N, Amann M, Ayeb-Karlsson S, Belesova K, Bouley T, Boykoff M, Byass P, Cai W, CampbellLendrum D, Chambers J, Cox PM, Daly M, Dasandi $N$, Davies $M$, Depledge $M$, Depoux A, DominguezSalas P, Drummond P, Ekins P, Flahault A, Frumkin $H$, Georgeson L, Ghanei M, Grace D, Graham H, Grojsman $R$, Haines A, Hamilton $I$, Hartinger $S$, Johnson A, Kelman I, Kiesewetter $G$, Kniveton D, Liang L, Lott M, Lowe R, Mace G, Odhiambo Sewe M, Maslin M, Mikhaylov S, Milner J, Latifi AM, MoradiLakeh M, Morrissey K, Murray K, Neville T, Nilsson M, Oreszczyn T, Owfi F, Pencheon D, Pye S, Rabbaniha M, Robinson E, Rocklöv J, Schütte S, Shumake-Guillemot $J$, Steinbach R, Tabatabaei $M$, Wheeler N, Wilkinson P, Gong P, Montgomery H, Costello A.: The Lancet Countdown on health and climate change: from 25 years of inaction to a global transformation for public health. The Lancet 2018;391(10120):581-630; doi: 10.1016/ S0140-6736(17)32464-9.

3. Kjellstrom T., Briggs D., Freyberg C., Lemke, B., Otto, M., \& Hyatt, O.: Heat, human performance, and occupational health: a key issue for the assessment of global climate change impacts. Annual review of public health, 2016;37:97-112, doi: 10.1146/annurevpublhealth-032315-021740.

4. Hassanin N. M., Awad O. M., El-Fiki S., Abou-Shanab R. A., Abou-Shanab A. R., \& Amer R. A.: Association between exposure to pesticides and disorder on hematological parameters and kidney function in male agricultural workers. Environmental Science and Pollution Research, 2018;25(31):30802-30807 doi:10.1007/s11356-017-8958-9.

5. McMichael AJ:: Globalization, climate change, and human health. N Engl J Med 2013;368(14):1335-43. doi: 10.1056/NEJMra1109341.

6. Glaser J., Lemery J., Rajagopalan B., Diaz H. F., García-Trabanino R., Taduri G., Anutrakulchai S.: Climate change and the emergent epidemic of CKD from heat stress in rural communities: the case for heat stress nephropathy. Clin J Am Soc Nephrol, 2016; 11(8): 1472-1483. doi: 10.2215/CJN.13841215.

7. ACGIH, Threshold limit values for chemical substances and physical agents and biological exposure indices. $\mathrm{OH}$, in American Conference of Governmental Industrial Hygienists. 2017, American Conference of Governmental Industrial Hygienists (ACGIH): Cincinnati.

8. Nerbass FB, Pecoits-Filho R, Clark WF, Sontrop $J M$, McIntyre CW, Moist L.: Occupational Heat Stress and Kidney Health: From Farms to Factories. Kidney Int Rep. 2017 Aug 31;2(6):998-1008. doi: 
10.1016/j.ekir.2017.08.012. PMID: 29270511; PMCID: PMC5733743.

9. Wesseling C, Glaser J, Rodríguez-Guzmán J, Weiss I, Lucas R, Peraza S, da Silva AS, Hansson E, Johnson $R J$, Hogstedt C, Wegman DH, Jakobsson K: Chronic kidney disease of non-traditional origin in Mesoamerica: a disease primarily driven by occupational heat stress. Rev Panam Salud Publica. 2020 Jan 27;44:e15. doi: 10.26633/RPSP.2020.15. PMID: 31998376; PMCID: PMC6984407.

10. ACGIH, Heat Stress and Strain: TLV® Physical Agents, in American Conference of Governmental Industrial Hygienists (American Conference of Government Industrial Hygienists 2009, OH: ACGIH. : Cincinnati.

11. Mills KT, Xu Y, Zhang W, Bundy JD, Chen CS, Kelly $T N$, Chen J, He J.: A systematic analysis of worldwide population-based data on the global burden of chronic kidney disease in 2010. Kidney Int. 2015 Nov;88(5):9507. doi: 10.1038/ki.2015.230. Epub 2015 Jul 29. PMID: 26221752; PMCID: PMC4653075.

12. Ekiti, M. E., Zambo, J.-B., Assah, F. K., Agbor, V. N., Kekay, K., \& Ashuntantang, G. Chronic kidney disease in sugarcane workers in Cameroon: a cross-sectional study. BMC Nephrology, 2018 Jan 15;19(1):10. doi: 10.1186/s12882-017-0798-9.

13. Jakreng, C., Padungtod, C., Wittayapun, Y., Wasuwithitkul, S., \& Ekpanyaskul, C.: Occupational natural heat exposure and its health effects on salt production workers in Samutsongkhram province, Thailand. Occupational and environmental medicine, 2011; 68(Suppl 1), A118-A118 doi: 10.1136/ oemed-2011-100382.394.

14. Department of Labour Protection and Welfare. Regulation and method of heat, light and sound measurement, D.o.L.P.a. Welfare, Editor. 2018;11-16.

15. Weiner, D. E., McClean, M. D., Kaufman, J. S., \& Brooks, D. R.: The central American epidemic of CKD. Clin J Am Soc Nephrol, 2013;8(3):504-511 doi: 10.2215/ CJN.05050512.

16. EPA/OSHA. Guide to Heat Stress in Agriculture. US Environmental Protection Agency, Occupational Safety and Health Administration, 1993.

17. Langkulsen U., N. Vichit-Vadakan, and S. Taptagaporn: Health impact of climate change on occupational health and productivity in Thailand. Global Health Action, 2010;3(1):5607 doi:10.3402/gha.v3i0.5607.

18. Popowski LA, Oppliger RA, Patrick Lambert G, Johnson RF, Kim Johnson A, Gisolf CV: Blood and urinary measures of hydration status during progressive acute dehydration. Med Sci Sports Exerc. 2001 May;33(5):747-53. doi: 10.1097/00005768-20010500000011. PMID: 11323543.

19. Cheuvront, S. N., Ely, B. R., Kenefick, R. W., \& Sawka, M. N.: Biological variation and diagnostic accuracy of dehydration assessment markers. Am J Clin Nutr, 2010;92(3):565-573 doi:10.3945/ajen.2010.29490.

20. Nanayakkara, I., Dissanayake, R. K., \& Nanayakkara, $S$.: The presence of dehydration in paddy farmers in an area with chronic kidney disease of unknown aetiology. Nephrology, 2020;25(2):156-162 doi:10.1111/nep.13605.

21. Ueno S., Sakakibara Y., Hisanaga, N., Oka, T., \& Yamaguchi-Sekino, S.: Heat strain and hydration of Japanese construction workers during work in summer. Annals of Work Exposures and Health, 2018; 62(5):571582. doi:10.1093/annweh/wxy012.

22. Polkinghorne B. G., Gopaldasani, V., Furber, S., Davies, B.,Flood, V. M.: Hydration status of underground miners in a temperate Australian region. BMC Public Health 2013;3(1):1-8 doi:10.1186/1471-2458-13-426.

23. Elinder C., Wernerson, A.,Wijkstrom J.: Mesoamerican nephropathy (MeN). A "new" chronic kidney disease related to occupational heat exposure with repeated deprivation of salts and water. Int $J$ Nephrol Kidney Fail, 2015;1(2), 1-9 doi: http://dx.doi.org/10.16966/23805498.109.

24. CKD-EPI Creatinine Equation 2009. [cited 2019] Available from: https://www.kidney.org/content/ckdepi-creatinine-equation-2009.

25. Laws RL, Brooks DR, Amador JJ, Weiner DE, Kaufman $J S$, Ramírez-Rubio O, Riefkohl A, Scammell MK, López-Pilarte D, Sánchez JM, Parikh CR, McClean $M D$.: Changes in kidney function among Nicaraguan sugarcane workers. Int J Occup Environ Health. 2015 Jul-Sep;21(3):241-50. doi: 10.1179/2049396714Y.00000 00102 .

26. Garcia-Trabanino R, Jarquín E, Wesseling C, Johnson RJ, González-Quiroz M, Weiss I, Glaser J, José Vindell J, Stockfelt L, Roncal C, Harra T, Barregard L.: Heat stress, dehydration, and kidney function in sugarcane cutters in El Salvador - A cross-shift study of workers at risk of Mesoamerican nephropathy. Environ Res. 2015Oct;142:746-55. doi: 10.1016/j.envres.2015.07.007. Epub 2015 Jul 23. PMID: 26209462.

27. Butler-Dawson J, Krisher L, Yoder H, Dally M, Sorensen C, Johnson RJ, Asensio C, Cruz A, Johnson EC, Carlton EJ, Tenney L, Asturias EJ, Newman LS.: Evaluation of heat stress and cumulative incidence of acute kidney injury in sugarcane workers in Guatemala. Int Arch Occup Environ Health. 2019 Oct;92(7):977990. doi: 10.1007/s00420-019-01426-3. Epub 2019 Apr 17. PMID: 30997573; PMCID: PMC6768910.

Received: 04.09.2021

Accepted: 04.11.2021

Published online first: 09.11.2021 